\title{
The Histomorphology of Colonic Behcet's Disease
}

Yilmaz Bas

*Correspondence: yilbas@yahoo.com

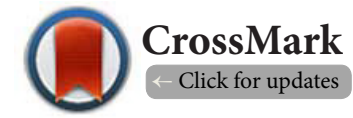

Department of Pathology, Hitit University, Education and Research Hospital, Corum, Turkey.

\begin{abstract}
Intestinal Behçet's Disease (BD) may manifests with several signs varying from superficial and deep ulcers to massive bleeding and colon perforation. Both mucosal ulcer and inflammation observed as a result of the affected small diameter vessels and ischemic damage findings due to the affected large diameter vessels are significantly associated with morbidity and mortality. In addition, differential diagnosis may be histomorphologically challenging particularly in other diseases involving colon lesions. These histomorphologic findings become important because of the lacking a pathognomonic test for definitive diagnosis. This article discusses histomorphological findings of BD that are much more important in pathology pratics of in addition to epidemiological, etiological and clinical features of the disease.
\end{abstract}

Keywords: Colon, Behcet's disease, histomorphologic findings

\section{Introduction}

Behcet's disease (BD) is a disorder characterized with multi system involvement, involving prolonged inflammation and vasculitis signs [1-8]. BD progresses with unpredictable exarcerbation and remissions [5,8]. Triple syndrome characterized by eye lesions, recurrent oral and genital ulcers has been described by the first time by Hulusi Behçet in $1937[\mathbf{2 , 4}, \mathbf{5}, \mathbf{9}]$. It may present vascular, articular, gastrointestinal, neurologic, ocular, urogenital, pulmonary and cardiac involvement [1-5]. Gastrointestinal system involvement has been described for the first time in 1940 [5]. The definition of "intestinal Behçet's disease" has been proposed by Japan researchers in 1964 [10]. Intestinal involvement involves important clinical and pathological findings varying from superficial and deep ulcers to massive bleeding and colon perforation [3,10-12]. Colon involvement is significantly associated with morbidity and mortality [3,11-13]. Three sets have been determined for using in clinical diagnosis including The International Study Group (ISG) $[15,17,18]$, International Criteria for Behçet's Disease-2014 (ICBD) $[\mathbf{2 , 7}, \mathbf{1 4 , 1 5 , 1 8 ]}$ and International Pediatric Criteria for BD-2015 [16]. Unfortunately, there is no a pathognomonic test for the diagnosis of $\mathrm{BD}[2,3, \mathbf{5}]$. The diagnosis of intestinal $\mathrm{BD}$, especially that of Behçet's colitis can be established by ruling out the diseases included in the differential diagnosis and demonstrating the presence of triple symptoms. However, in the cases making the diagnosis difficult such as superficial and deep ulcers and/ or colon perforation with unclear reason; branches such as pathology, surgery, dermatology, rheumatology and radiology should be involved in a fast approach coordinated with each other, guiding the diagnosis and treatment. If the pathologist is unable to set a definitive diagnosis, he/she should describe the priority diagnosis by order in the report.

\section{Epidemiology}

Behçet's disease is more common in the countries located along the historical silk road from eastern Asia to the Mediterranean basin $[\mathbf{2}, \mathbf{3}, \mathbf{4}, \mathbf{1 2}, \mathbf{1 9}]$. In Turkey, 20/80-420 cases per 100,000

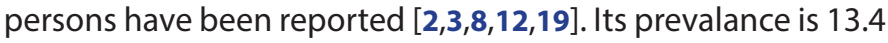
in 100,000 in Japan and 14.0 in 100,000 in China. In contrast, its prevalance is $0.27-5.2$ cases per 1 million personsin the United States of America (USA) and north European countries $[3,19]$. There is a close association between the geographical distribution human leukocyte antigen (HLA)-B51 and the prevalance of BD. The incidence of HLA-51 is $20-25 \%$ in the general population residing along the silk road and $50-80 \%$ among the population with BD. However, while the incidence is $2-8 \%$ in the population living in the noth European countries and the USA, this rate is $15 \%$ among people with $\mathrm{BD}$ who live in these regions [5].

The prevalance of intestinal involvement becomes more common from the Mediterranean basin toward the eastern Asia, differing between $0 \%$ and $60 \%[1,2,10,12,14,20]$. The 
Yilmaz Bas, Gastroenterological and Intestinal Systems 2017,

clinical findings show difference among both immigrants and different geographic regions $[2,5]$. For example, gastrointestinal system (GIS) involvement is much more frequent in far east Asia, particularly in Japan (55-60\%) $[2, \mathbf{3}, \mathbf{5}]$. Whereas, the incidence of intestinal BD is $1.4-3 \%$ in Turkey [3,5]. There is intestinal involvement in one third of the patients in the USA [2]. The incidence of vascular involvement is $7 \%$ to $29 \%$ [3]. Onset of the disease is $3-4$ decades of life $[2,3,5]$. Both sexes are equally affected with the course of the disease is more severe in men [2].

\section{Etiopathogenesis \\ Infectious agents}

The most likely hypothesis is an inflammation caused by herpes simplex virus or an autoantigen such as "heat shock protein" in genetically predisposed individuals or by infections agents similar to Streptococci species such as Streptococcus sanguinis [5]. It is thought that microbial load and related immune response occurring against "microbial 65KD shock protein" in the gums and aphtous ulcers of BD patients cross-react with "endogenous human $60 \mathrm{KD}$ heat shock protein", producing autoreactive $T$ cells clones and leading to immunopathological changes $[\mathbf{5 , 2 1}]$. Streptococcus sanguis and its antibodies have often been detected in the serum and oral mucosas in $\mathrm{BD}[1,9]$. The rate of Anti-Saccharomyces cerevisiae antibodies (ASCA) has been found as significantly higher in BD with GIS involvement compared with the control group [1]. ASCA is positive in $44.3 \%$ of the cases intestinal BD $[1,2]$.

\section{Genetical and immunological factors}

Four criteria support evidence of genetical impact in BD: Specific geographic distribution, familial predisposition, its relationship with Class I HLA antigen and polymorphism in the genes controlling immune responses $[8,12]$.

As geographical distribution, familial predisposition also differs among populations. Familial predisposition is higher in Turks (18.2\%), Koreans (15.4\%) and Jews (13.2\%) than in Chines people (2.6\%), Japans (2.2\%) and various European populations (0-4.5\%) [8].

Results of the numerous meta-analyses have shown that HLA-B51/5 allele is the strongest genetical susceptibility factor for BD $[5,22]$. The incidence of HLA-B51/5 allele is much higher in patients with $B D$ compared with the unaffected populations $[1-5,12,23]$. Furthermore, probability of the development of $B D$ has been found to be 5.78 times higher in HLA-B51/5 carriers than in persons who do not carry this antigen [22]. HLA-B51 allele is often seen in Turk and Japan patients with Behçet's disease $[\mathbf{8 , 2 4}]$. Another genetical suspectibility factor is "MHC class I polypeptide-related gene A" (MICA) $[1,25]$. Besides HLA-B51, HLA-B5101 in the MHC locus has been demonstrated to be more significantly associated with pathogenesis of the disease among the populations residing along the silk road [12].

In the gene polymorphism for BD; tumor necrotizing factor
(TNF)-1031C promoter gene polymorphism has been shown to be correlated with the disease independently from HLAB51 and HLA-B5101 [26]. Particularly IL-6 and TNF-a gene polymorphisms have been focused in Turkish population [27].

There are recent studies demonstrating the relationships between single-nucleotide polymorphisms of interleukin (IL) 10, IL23 receptor and (IL23R)/IL12 receptor $\beta 2$ (IL12RB2) genes and BD in Turkey and Japan $[1,5,9,23,29]$. IL23 which shares p40 subunit with IL12 acts to stimulate activation of the produced IL-17 T cell. Therefore, IL23 is one of the main Thelper (Th) 17 pathway activators [5]. Present data suggest that Th17 cells and IL17 may play a role in the development of BD disease and/or neutrophil activity and neutrophil chemotaxis $[5,16,22]$. IL-17 which is a proinflammatory cytokine directs the production of TNF, IL-1, IL-6, IL-8, and CXC ligand 1 from monocytes, stromal, epithelial and endothelial cells. These proinflammatory cytokines produced allow neutrophils to rapidly reach to inflammation site [30]. Lymphocytic infiltrates predominantly constitute CD3+ T cells [16]. Tissue and serum of $\mathrm{BD}$ patients contain Th1, Th17, CD4+ and CD8+ T cells, and activated $Y \delta+T$ cells $[1,20]$.

\section{Clinical/intestinal findings}

The lesions of intestinal BD may be found throughout the entire system along the Gl tract from the lips to the anus. Esophagogastoduodenal involvement is extremely rare and non-specific [10]. Number of the cases with esophagial involvement is less 50 worldwide, while number of the cases with gastric involvement is even lower [11]. Non-specific clinical findings may be observed as gastritis and/or gastric ulcer. No statical correlation has been found with helicobacter pylori compared to healthy control group [31]. Isolated ileum involvement is not uncommon [20]. Whereas ileocecal region is the most frequent involvement localization $[\mathbf{1}, \mathbf{2}, \mathbf{3}, \mathbf{1 0 , 2 0}]$. Occasionally transverse colon and ascending colon are involved [9]. Diffuse colonic, rectal and anorectal involvements are rare $[1,2]$. Hepatic problems are uncommon unless associated with Budd-Chiari syndrome [32].

GIS findings usually develops 4.5-6 years after the onset of oral ulcerations $[1,3,10]$. However, they may be seen before the beginning of other BD symptoms [10]. The symptoms in GIS involvement show similarity to those related to inflammatory bowel disease (IBD) [2]. BD has clinical findings differing from mild abdominal pain to colon perforation and massive bleeding $[\mathbf{1}, \mathbf{2}, \mathbf{1 3}, \mathbf{1 4}]$. Ulcers are mostly wider than 1 $\mathrm{cm}$, round-oval shaped $(77 \%)$, single $(67 \%)$ or several located seperately (27\%), sharply circumscribed, staple hole-like or perforated (Figures 1A and 1B). Abdominal pain, diarrhea and bleeding are the most common clinical symptoms $[10,13,33]$. These symptoms are often the result of mucosal ulcerations [2]. Perforation and penetration occur in $50 \%$ of patients with ulcers [32,34]. Based on type ve clinical findings ileocolic ulceration, an algorithm has been created for the diagnosis of BD [32] (Table 1). Histopathological lesion responsible for 


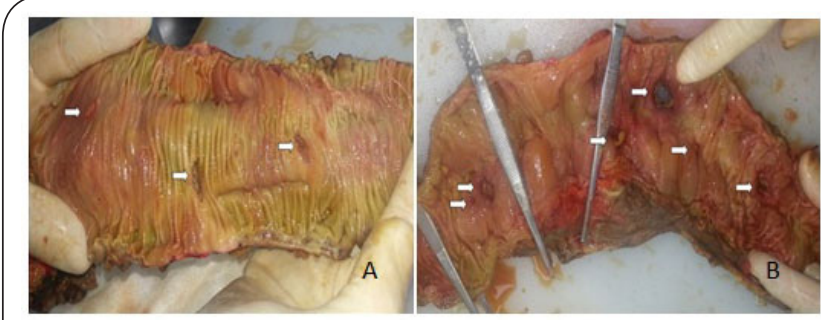

Figure 1. (A,B) Numerous wide, oval shaped, welldemarcated, staple hole-like ulcers and perforated ulcerated areas that are separated from the normal colonic mucosa with a marked border, in the oedematous colon resection [32].

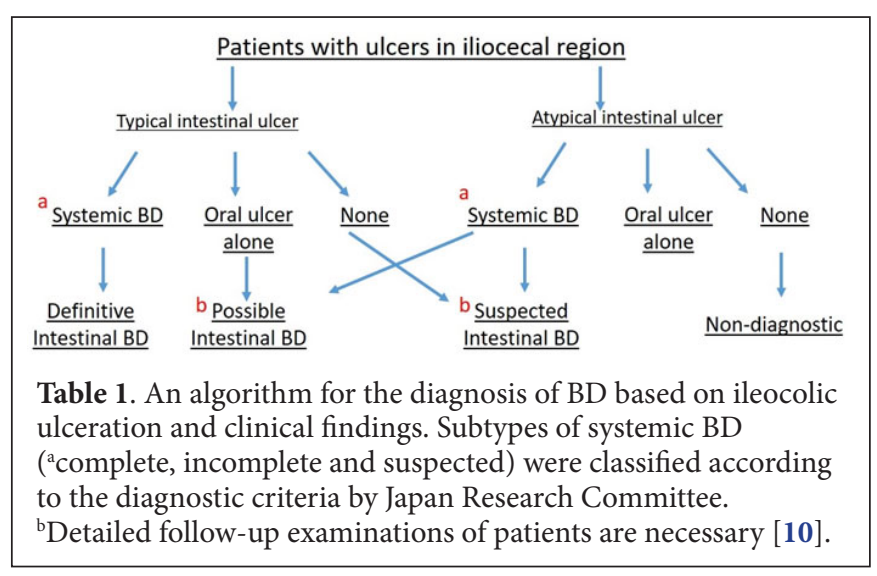

these clinical and morphological findings is vasculitis $[1,20,35]$. All dimensions of the arteries and veins may be involved in $\mathrm{BD}[3,32]$. Aneurysm and luminal thrombus are the arterial manifestations [3]. Whereas, radiographic findings are nonspecific [2]. Serum markers of inflammation such as C-reactive protein (CRP) and erythrocyte sedimentation rate may be high $[2,10]$. Antinuclear antibodies and Rheumatoid factor autoantibodies are not typically found [2].

There is no a definite relationship between BD and malignancies. However; solid tumors, haematological and lymphoid malignancies were detected during the course of $\mathrm{BD}$ [35-37].

\section{Morphological findings Macroscopic findings}

Theoretically, there are two forms of intestinal lesions. First is mucosal inflammation and ulcers produced by neutrophilic phlebitis as a result of the influence of small-diameter vessels. Second is ischemic damage developed due to vasculitis occurring as a result of the influence of large-diameter vessels $[1,38]$. Multisegmental and diffuse colonic involvement is seen by $6-22.2 \%[3,14]$. Mucosal inflammation and ulceration may occur throughout the GIS with typical ulcers are usually located in the ileocecal area by $88 \%[1,3,14,38-40]$. Ulcers are mostly wider than $1 \mathrm{~cm}$, round-oval shaped (77\%), single (67\%) or several located seperately (27\%), sharply circumscribed, staple hole-like or perforated [1-3,11,38,41] (Figures 1A,1B and 2).

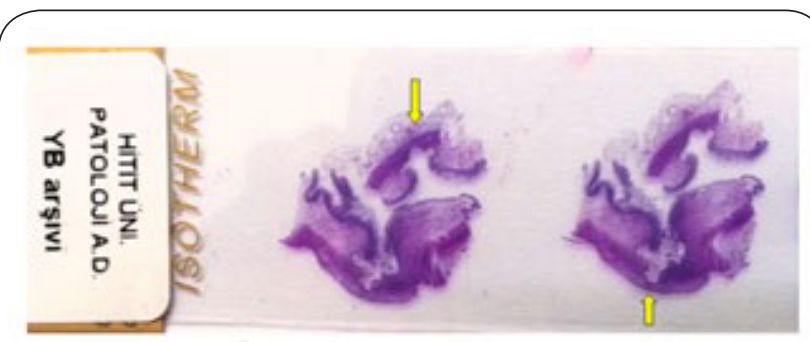

Figure 2. View of staple hole-like, sharply circumscribed ulcers in the tissue sections of the lesions belonging to $\mathrm{H} \& \mathrm{E}$ stained colon on the slide surface.

Staple hole-like lesion is specific for BD [6].

There are less than 6 ulcers in $85 \%$ of patients $[3,14]$ that are usually localized at the antimesenteric side [38]. The lesions differ in form from small aphthous ulcerations and multiple irregular shaped wide ulcers [1]. The mean diameter of ulcers is $2.9 \mathrm{~cm}[3,39]$. The deep ulcers are more common (68\%) $[3,39]$ (Figure 2). These ulcers are macroscopically divided into three types as volcanic, geographic and aphthous $[1,39]$. Volcanic type ulcers are in the form of lesions with converging folds or pseudopolyp structures or well-circumscribed lesions with nodular margins, showing deep penetration [1]. Increased fibrous tissue in ulcer margins cause to a nodular appearance [2].

\section{Microscopic findings}

Histological findings related to intestinal BD are not pathognomonic $[1,20]$.

A wide necrosis and ulcer surrounded all around with normal mucosa are also one of the characteristic histological findings of intestinal $B D[1,11]$. Submucosal connective tissue damage is prominent in deep ulcers $[32,39,41]$. The ulcer base is swollen due to edema. The ulcer edges are crater shaped $[32,41]$. (Figures $3 \mathrm{~A}$ and $3 \mathrm{~B}$ ). Formation of non-caseified epithelioid granuloma is not an expected finding [1], but may be occasionally observed [14].

In the examination of the resected specimen; nonspecific inflammatory reaction with predominant neutrophils, lymphocytes and plasma cells, granulation tissue and fibroplasia may be seen especially in the ulcerous lesions $[1,5,11,13,14,20]$.

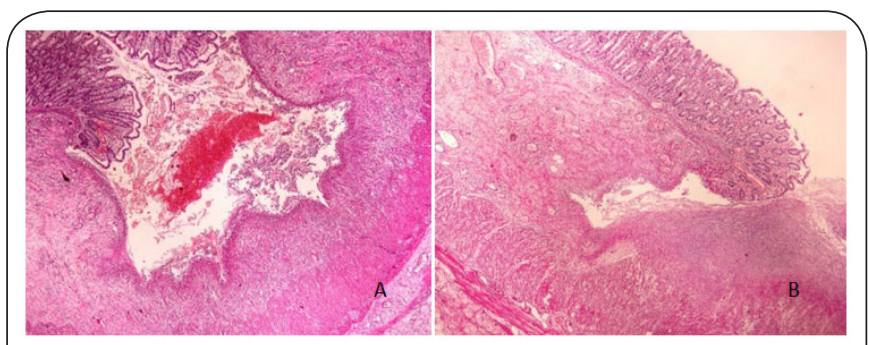

Figure 3. (A,B) Sharply circumscribed deep necrosis and ulcers showing continuity with the colon surface (H\&E, x100). 
Yilmaz Bas, Gastroenterological and Intestinal Systems 2017,

Crypt abscesses, submucosal fibrosis and inflammation in the intact mucosa may be observed in the resected specimen in the cases without macroscospic ulcer [20].

In addition, vasculitis which is a characteristic finding is better evaluated in the resected specimen $[5,32]$. However, vasculitis is rarely observed in endoscopic and small surgical specimen [10]. In general, small-diameter vessels, especially submucosal venules are involved but arterioles may also be involved [5,32] (Figures 4A-4D inset). The presence of vasculitis with affected small veins and venules is a strong histologic sign for the diagnosis [1,14] (Figures 4A and 4B). Vascular inflammation shows diffuse form rather patched form and involves vaist majority of vessel walls [42]. It is characterized by the mononuclear cells and neutrophilic infiltration in the wall were eosinophils are also observed [12,32] (Figure 4). Neutrophilic vascular reaction may be seen in many cases without vasculitis [5]. Extravasated erythrocytes may also observed. Diffuse venous thrombosis and focal myonecrosis are also frequently seen [12].

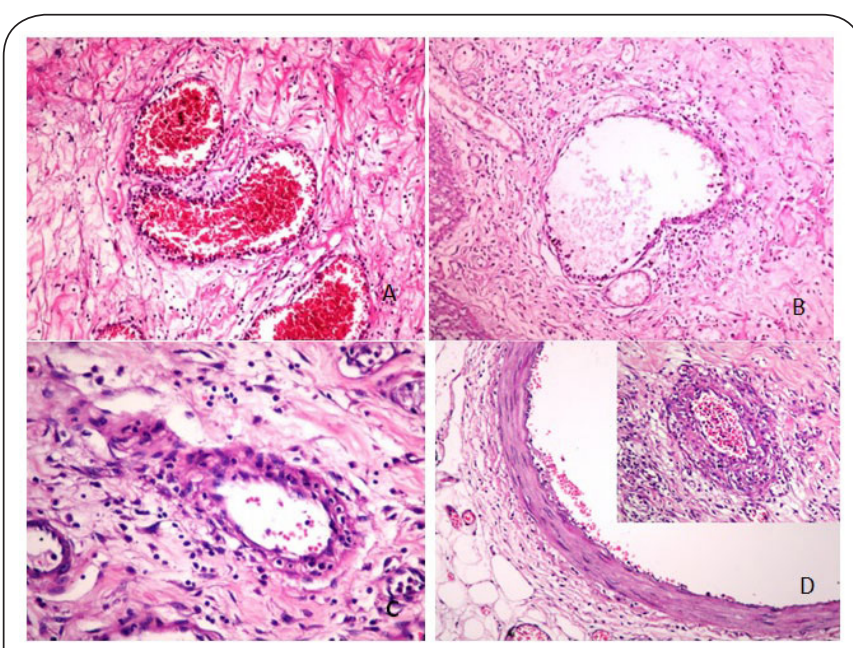

Figure 4. (A,B,C) Samples of venulitis including leukocytesrich inflammatory cellular reaction accompanied also with a small number of mononuclear leukocytes and eosinophils. Inflammation is marked also in the perivascular tissue $(\mathrm{H} \& \mathrm{E}$, x200). D, inset) Arteriolitis (H\&E, x400).

\section{Differential diagnosis}

Macro- and micro appearance of the lesions in BS and localization of the disease may resemble IBD, amibiasis, ischemic bowel disease or the lesions of drug-induced damage $[13,20,34]$. Furthermore, it should be remembered that tuberculosis is also endemic in the silk road geography [3]. Again, among the causes of colon perforation; spontaneous perforation, fecal retention and mass, "closed loop" obstruction, adynamic ileus, enterocolitis, diverticulitis, neoplasia, vasculitis and congenital defects of the intestinal wall should be taken into account in the differential diagnosis [32].

Clinical course, nonspecific gastrointestinal symptoms and extraintestinal findings show similarities in colonic BD and Crohn's diseases (CD), thus differentiation of these two disease is challenging. In addition, genetical features are also similar in both the diseases. The use of a diagnostic algorithm may be useful for macroscopic classification analysis [1] (Table 2).

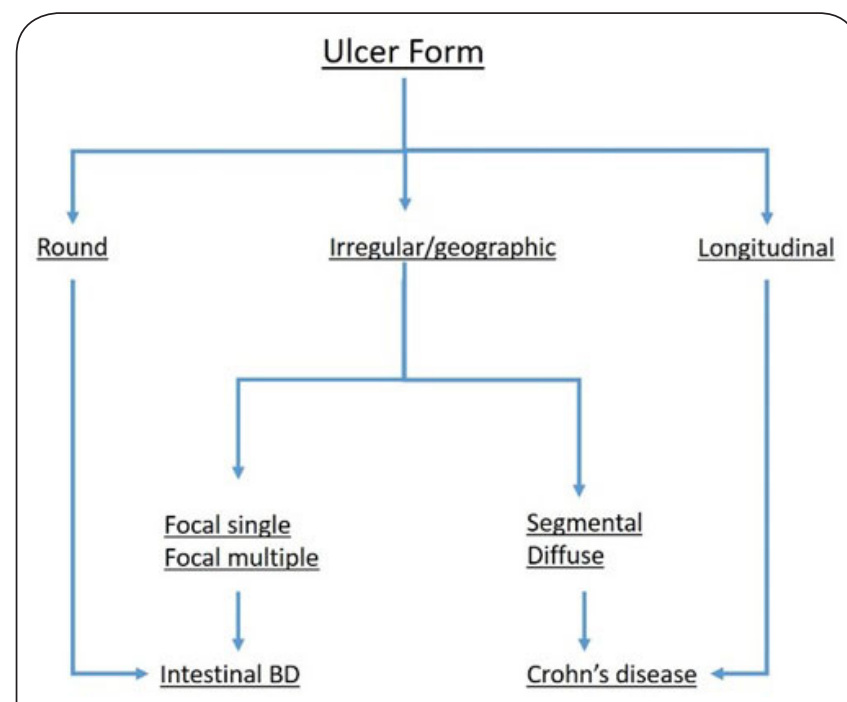

Table 2. Macroscopic diagnostic algorithm for the differential diagnosis between $\mathrm{BD}$ and $\mathrm{CD}[\mathbf{1}]$.

Oral ulcers and uvitis are more common in BD. Genital ulcers are an important characteristic in $B D$ and rarely seen in $C D$ [3]. Classical macroscopic findings of CD include intermittent chronic mucosal inflammation, aphthous ulcers, longitudinal ulcerations and "curbstone" appearance surrounded by normal mucosa [1,34]. Vaulter inflammatory lesions surrounded by normal mucosa are observed in both diseases, but this pattern is more diffuse in CD. Non-caseified granulomas are seen in $15-36 \%$ od CD cases [1]. Vasculitis is characteristric for BD [1]. ASCA rates are similar in both diseases [1]. Ulcerative colitis (UC) usually begins from the rectum and diffuse mucosal inflammation mixed with normal mucosa may also present [34]. Destruction of the superficial epithelium, polymorphonuclear leukocyte infiltration, loss of the goblet cells and damage in the crypts are more frequently encountered in patients with UC [1].

\section{Prognosis}

The rate of mortality from $\mathrm{BD}$ is significantly higher among young male patients, especially in the second and third decades of life [41]. Disease specific mortality is mainly due to major vessel disease (arterial aneurysm, Budd-Chiari syndrome) or neurologic involvement $[3,9,32]$. Poor prognostic factors including young patients, volcanic type ulcers, absence of the initial response to medical therapy, failure of mucosal healing, high CRP level, a history of postoperative corticosteroid treatment, macroscopic detection of perforation, diffuse ileal disease, presence of ocular disease and ASCA positivity $[2,13]$. 
Yilmaz Bas, Gastroenterological and Intestinal Systems 2017, http://www.hoajonline.com/journals/pdf/2054-4154-5-1.pdf

Death from intestinal BD is infrequent [3]. However, presence of intestinal lesions can be considered as a poor prognostic factor [33]. In a 20-year retrospective study conducted by Istanbul University, $10.9 \%$ of patients with Behçet's disease had died [43]. The rate of remission within the first 8 weeks after initiation of medical therapy has been reported as $38-67 \%$ in intestinal BD cases. Cumulative rates of surgical intervention have been reported as 20 within the first year after the diagnosis, $27-33 \%$ within 5 years and $31-46 \%$ within 10 years [13]. Recurrence in the anastomosis line or in its neighborhood is seen in $40-80 \%$ of the patients [2].

\section{Treatment approach}

Treatment approach is directed to wide vessel vasculitis as well as to ocular, intestinal and central nervous system symptoms based on the clinical findings, planned in a multidisciplinary approach [2,32]. 5-aminosalicylic acid, systemic corticosteroids, immunomodulators and anti-tumor necrotizing factor alpha monoclonal antibody treatments are used successfully $[3,10]$. Novel treatment approaches focuse on targeted cytokines such as TNF- $a$, IL-21 and IL-17 [12]. In the consensus that has been achieved in 2013 on the diagnosis and treatment approach of BD, anti-TNFa monoclonal antibody therapy was recommended as a standard treatment [33]. Sever bleeding, perforation, fistula, obstruction, abdominal mass and unresponsiveness to medical therapy are the endications for surgical intervention $[2,6,10,13]$.

\section{Competing interests}

The author declares that he has no competing interests.

\section{Acknowledgement}

I thank my colleagues (Ms. B. Hande Erenler, Ms. H. Hande

Keser) for their support.

\section{Publication history}

EIC: Zsolt Tulassay, Semmelweis University, Hungary.

Received: 25-Apr-2017 Accepted: 28-May-2017

Published: 09-Jun-2017

\section{References}

1. Kim DH and Cheon JH. Intestinal Behcet's Disease: A True Inflammatory Bowel Disease or Merely an Intestinal Complication of Systemic Vasculitis? Yonsei Med J. 2016; 57:22-32. | Article | PubMed Abstract | PubMed FullText

2. Chin $A B$ and Kumar AS. Behcet colitis. Clin Colon Rectal Surg. 2015; 28:99-102. | Article | PubMed Abstract | PubMed FullText

3. Skef W, Hamilton MJ and Arayssi T. Gastrointestinal Behcet's disease: a review. World J Gastroenterol. 2015; 21:3801-12. | Article | PubMed Abstract | PubMed FullText

4. Paovic J, Paovic P and Sredovic V. Behcet's disease: systemic and ocular manifestations. Biomed Res Int. 2013; 2013:247345. | Article | PubMed Abstract | PubMed FullText

5. Alpsoy E. Behcet's disease: A comprehensive review with a focus on epidemiology, etiology and clinical features, and management of mucocutaneous lesions. J Dermatol. 2016; 43:620-32. | Article | PubMed

6. Adiamah A and Wong LS. Bechet's disease: a rare cause of rectovaginal fistula. BMJ Case Rep. 2010; 2010. | Article | PubMed Abstract | PubMed
FullText

7. Davatchi F, Chams-Davatchi C, Shams H, Nadji A, Faezi T, Akhlaghi M, Sadeghi Abdollahi B, Ashofteh F, Ghodsi Z, Mohtasham N and Shahram F. Adult Behcet's disease in Iran: analysis of $\mathbf{6 0 7 5}$ patients. Int J Rheum Dis. 2016; 19:95-103. | Article | PubMed

8. Takeuchi M, Kastner DL and Remmers EF. The immunogenetics of Behcet's disease: A comprehensive review. J Autoimmun. 2015; 64:13748. | Article | PubMed Abstract | PubMed FullText

9. Saadoun D and Wechsler B. Behçet's disease. Orphanet J Rare Dis. 2012; $7: 20$.

10. Cheon JH and Kim WH. An update on the diagnosis, treatment, and prognosis of intestinal Behcet's disease. Curr Opin Rheumatol. 2015; 27:24-31. | Article | PubMed

11. Shin DY, Cheon JH, Park JJ, Kim H, Kim TI, Lee YC, Kim NK and Kim WH. [Serial episodes of gastric and cecal perforation in a patient with Behcet's disease involving the whole gastrointestinal tract: a case report]. Korean J Gastroenterol. 2009; 53:106-10. | Article I PubMed

12. Zeidan MJ, Saadoun D, Garrido M, Klatzmann D, Six A and Cacoub P. Behcet's disease physiopathology: a contemporary review. Auto Immun Highlights. 2016; 7:4. | Article | PubMed Abstract | PubMed FullText

13. Park JJ, Kim WH and Cheon JH. Outcome predictors for intestinal Behcet's disease. Yonsei Med J. 2013; 54:1084-90. | Article | PubMed Abstract I PubMed FullText

14. Zou J, Shen Y, Ji DN, Zheng SB and Guan JL. Endoscopic findings of gastrointestinal involvement in Chinese patients with Behcet's disease. World J Gastroenterol. 2014; 20:17171-8. | Article | PubMed Abstract | PubMed FullText

15. Davatchi F. Diagnosis/Classification Criteria for Behcet's Disease. Patholog Res Int. 2012; 2012:607921. | Article | PubMed Abstract | PubMed FullText

16. Kone-Paut I. Behcet's disease in children, an overview. Pediatr Rheumatol Online J. 2016; 14:10. | Article | PubMed Abstract | PubMed FullText

17. Criteria for diagnosis of Behcet's disease. International Study Group for Behcet's Disease. Lancet. 1990; 335:1078-80. | PubMed

18. The International Criteria for Behcet's Disease (ICBD): a collaborative study of $\mathbf{2 7}$ countries on the sensitivity and specificity of the new criteria. J Eur Acad Dermatol Venereol. 2014; 28:338-47. | Article | PubMed

19. Barry RJ, Markandey B, Malhotra R, Knott H, Joji N, Mubin M, Denniston AK and Murray PI. Evidence-based practice in Behcet's disease: identifying areas of unmet need for 2014. Orphanet J Rare Dis. 2014; 9:16. | Article | PubMed Abstract | PubMed FullText

20. Koklu S, Yuksel O, Onur I, Unverdi S, Biyikoglu I, Akbal E, Sengul D, Unverdi $\mathrm{H}$ and Eksioglu M. Ileocolonic involvement in Behcet's disease: endoscopic and histological evaluation. Digestion. 2010; 81:214-7. | Article | PubMed

21. Direskeneli $H$ and Saruhan-Direskeneli $G$. The role of heat shock proteins in Behcet's disease. Clin Exp Rheumatol. 2003; 21:S44-8. | PubMed

22. Maldini $C$, Lavalley MP, Cheminant $M$, de Menthon M and Mahr A. Relationships of HLA-B51 or B5 genotype with Behcet's disease clinical characteristics: systematic review and meta-analyses of observational studies. Rheumatology (Oxford). 2012; 51:887-900. | Article | PubMed

23. Kaya TI. Genetics of Behcet's Disease. Patholog Res Int. 2012; 2012:912589. | Article | PubMed Abstract | PubMed FullText

24. Gul A, Hajeer AH, Worthington J, Ollier WE and Silman AJ. Linkage mapping of a novel susceptibility locus for Behcet's disease to chromosome 6p22-23. Arthritis Rheum. 2001; 44:2693-6. | PubMed

25. Ombrello MJ, Kirino Y, de Bakker PI, Gul A, Kastner DL and Remmers $\mathrm{EF}$. Behcet disease-associated $\mathrm{MHC}$ class I residues implicate antigen binding and regulation of cell-mediated cytotoxicity. Proc Natl Acad Sci U S A. 2014; 111:8867-72. | Article | PubMed Abstract | PubMed FullText

26. Ahmad T, Wallace GR, James T, Neville M, Bunce M, Mulcahy-Hawes K, Armuzzi A, Crawshaw J, Fortune F, Walton R, Stanford MR, Welsh KI, Marshall SE and Jewell DP. Mapping the HLA association in Behcet's 
Yilmaz Bas, Gastroenterological and Intestinal Systems 2017,

disease: a role for tumor necrosis factor polymorphisms? Arthritis Rheum. 2003; 48:807-13. | Article | PubMed

27. Amirzargar A, Shahram F, Nikoopour E, Rezaei N, Saeedfar K, Ziaei N and Davatchi F. Proinflammatory cytokine gene polymorphisms in Behcet's disease. Eur Cytokine Netw. 2010; 21:292-6. | Article | PubMed

28. Gul A. Pathogenesis of Behcet's disease: autoinflammatory features and beyond. Semin Immunopathol. 2015; 37:413-8. | Article | PubMed

29. Choe JY, Lee H, Kim SG, Kim MJ, Park SH and Kim SK. The distinct expressions of interleukin-15 and interleukin-15 receptor alpha in Behcet's disease. Rheumatol Int. 2013; 33:2109-15. | Article | PubMed

30. Furuzawa-Carballeda J, Vargas-Rojas MI and Cabral AR. Autoimmune inflammation from the Th17 perspective. Autoimmun Rev. 2007; 6:16975. | Article | PubMed

31. Cakmak SK, Cakmak A, Gul U, Sulaimanov M, Bingol P and Hazinedaroglu MS. Upper gastrointestinal abnormalities and Helicobacter pylori in Behcet's disease. Int J Dermatol. 2009; 48:1174-6. | Article | PubMed

32. Bas Y, Guney G, Uzbay P, Zobaci E, Ardali S and Ozkan AT. Colon perforation and Budd-Chiari syndrome in Behcet's disease. Am J Case Rep. 2015; 16:262-7. | Article | PubMed Abstract | PubMed FullText

33. Hisamatsu T, Ueno F, Matsumoto T, Kobayashi K, Koganei K, Kunisaki R, Hirai F, Nagahori M, Matsushita M, Kishimoto M, Takeno M, Tanaka M, Inoue $\mathrm{N}$ and Hibi T. The 2 nd edition of consensus statements for the diagnosis and management of intestinal Behcet's disease: indication of anti-TNFalpha monoclonal antibodies. J Gastroenterol. 2014; 49:156-62. | Article | PubMed Abstract | PubMed FullText

34. Sekmen U, Muftuoglu T, Sagiroglu J and Gungor O. Multiple perforations along the entire colon as a complication of intestinal Behcet's disease: a rare case. Saudi J Gastroenterol. 2008; 14:85-7. | Article | PubMed Abstract | PubMed FullText

35. Cengiz M, Altundag MK, Zorlu AF, Gullu IH, Ozyar E and Atahan IL. Malignancy in Behcet's disease: a report of 13 cases and a review of the literature. Clin Rheumatol. 2001; 20:239-44. | PubMed

36. Ahn JK, Oh JM, Lee J, Koh EM and Cha HS. Behcet's disease associated with malignancy in Korea: a single center experience. Rheumatol Int. 2010; 30:831-5. | Article | PubMed

37. Lin Y, Li G, Zheng W, Tian X and Zhang F. Behcet's disease associated with malignancy: a report of 41 Chinese cases. Int J Rheum Dis. 2014; 17:45965. | Article | PubMed

38. Yang XN, Ye ZS, Fan YY and Hu YQ. Prolonged small vessel vasculitis with colon mucosal inflammation as first manifestations of Behcet's disease. World J Gastroenterol. 2014; 20:4110-4. | Article | PubMed Abstract | PubMed FullText

39. Lee HJ, Kim YN, Jang HW, Jeon HH, Jung ES, Park SJ, Hong SP, Kim TI, Kim $\mathrm{WH}, \mathrm{Nam} \mathrm{CM}$ and Cheon JH. Correlations between endoscopic and clinical disease activity indices in intestinal Behcet's disease. World $\mathrm{J}$ Gastroenterol. 2012; 18:5771-8. | Article | PubMed Abstract | PubMed FullText

40. Dalvi SR, Yildirim R and Yazici Y. Behcet's Syndrome. Drugs. 2012; 72:2223-41. | Article | PubMed

41. Chou SJ, Chen VT, Jan HC, Lou MA and Liu YM. Intestinal perforations in Behcet's disease. J Gastrointest Surg. 2007; 11:508-14. | Article | PubMed Abstract | PubMed FullText

42. Seyahi E and Yurdakul S. Behcet's Syndrome and Thrombosis. Mediterr J Hematol Infect Dis. 2011; 3:e2011026. | Article | PubMed Abstract | PubMed FullText

43. Sibley C, Yazici Y, Tascilar K, Khan N, Bata Y, Yazici H, Goldbach-Mansky $\mathrm{R}$ and Hatemi $\mathrm{G}$. Behcet syndrome manifestations and activity in the United States versus Turkey -- a cross-sectional cohort comparison. $J$ Rheumatol. 2014; 41:1379-84. | Article | PubMed Abstract | PubMed FullText

\section{Citation:}

Bas Y. The Histomorphology of Colonic Behcet's

Disease. Gasteroentrol Intest Syst. 2017; 5:1.

http://dx.doi.org/10.7243/2054-4154-5-1 